\title{
Pulmonary adenocarcinoma in cattle
}

\section{Adenocarcinoma pulmonar en bovinos}

\author{
Diogo Sousa $Z,{ }^{1} \mathrm{MV}$, Luis Rivera $\mathrm{C}_{1}{ }^{2 *} \mathrm{MVZ}$, Didier Quevedo $\mathrm{C}_{1}{ }^{1} \mathrm{M} . \mathrm{Sc}$, \\ Ana Claudia Gorino, ${ }^{1}$ MV, Simone Biagio C, ${ }^{1}$ Ph.D, Renée Laufer A, ${ }^{1}$ Ph.D.
}

'São Paulo State University "Júlio de Mesquita Filho" (UNESP), Faculty of Veterinary and Zootechnical Medicine, Clinical Veterinary Department, Botucatu, São Paulo, Brasil. ${ }^{2}$ São Paulo State University "Júlio de Mesquita Filho" (UNESP), Faculty of Agricultural and Veterinary Sciences, Veterinary Pathology Department, Jaboticabal, São Paulo, Brasil. Correspondence: Igriveramvz@gmail.com

Received: November 2013; Accepted: April 2014.

\begin{abstract}
The Macroscopic, histological and immunohistochemical aspects of lung acinar adenocarcinoma and the presence of nodules in the abdominal cavity of an adult female bovine are reported. In the necropsy analysis samples were collected from the: lung, heart, spleen, liver, pancreas, kidney, uterus, intestine, brain, and from nodules found in the lung and abdominal cavity, which were routinely processed to be stained by hematoxylin-eosin and for an immunohistochemistry exam with the antibodies: cytokeratin (dilution $1: 200 \mu \mathrm{L}$ ) and vimentin (dilution $1: 1000 \mu \mathrm{L}$ ). The histopathological examination revealed neoplastic epithelial cells with acini formation. The immunohistochemical examination of the tumor cells showed positive marking for cytokeratin and the absence of marking for vimentin. According to anatomical, morphological, and histopathological findings, as well as the result of the immunohistochemical examination, the tumor was characterized as lung acinar adenocarcinoma.
\end{abstract}

Key words: Histopathology, immunochemistry, lung, metastasis, neoplasia (Source: $C A B$ ).

\section{RESUMEN}

Se relatan los aspectos macroscópicos, histológicos e inmunohistoquímicos de un adenocarcinoma acinar pulmonar y la presencia de nódulos en la cavidad abdominal en una hembra bovina adulta. En el análisis necroscópico fueron colectados fragmentos de: pulmón, corazón, bazo, hígado, páncreas, riñón, útero, intestino, encéfalo y de los nódulos hallados en pulmón y cavidad abdominal, los cuales fueron procesados rutinariamente para ser teñidos mediante Hematoxilina-Eosina y para examen inmunohistoquímico con los anticuerpos: citoqueratina (con dilución 1:200 $\mu \mathrm{L}$ ) y vimentina (dilución $1: 1000 \mu \mathrm{L}$ ). El examen histopatológico reveló células epiteliales neoplásicas con formación de acinos. El examen inmunohistoquímico de las células neoplásicas demostró marcación positiva para citoqueratina y ausencia de marcación para vimentina. De acuerdo con los hallazgos anatómicos, morfológicos, histopatológico, y el resultado del examen inmunohistoquímico, se logró caracterizar el tumor como adenocarcinoma acinar pulmonar.

Palabras clave: Histopatología, inmunohistoquímica, metástasis, neoplasia, pulmón (Fuente: CAB). 


\section{INTRODUCTION}

Primary lung tumors are rare in cattle, so it is an unusual finding in slaughterhouses. The incidence of these tumors is $2.8 \%$ among all neoplasms found in the species (1).

Malignant tumors of epithelial origin related to lung tissue in cattle may arise from the epithelium, bronchial mucous glands (goblet cells) and alveolar liner. These tumors can be subdivided into four different histological types: papillary, acinar, solid and mixed, the papillary and acinar types are the most common in domestic animals (2).

Metastasis of lung carcinomas occurs due to local invasion by a hematogenous or lymphatic route (1). Due to the rare frequency of this neoplasm in cattle, little is known about its biological behavior. In Brazil, in a retrospective study performed by Lucena et al (3), between 1964 and 2008, samples were obtained in paraffin blocks from bovine necropsies performed on 6706 cattle, stored in the Pathology Service archives, at St. Mary's University, Rio Grande do sul. Of these samples, 586 were neoplasms. It was determined that four adenocarcinomas were of pulmonary origin, including two papillary adenocarcinomas, one acinar and one of small anaplastic cells. However, Viott et al (4) described, in detail, the first case of pulmonary adenocarcinoma in this country.

The aim of this study was to report the occurrence and describe the macroscopic, histological and immunohistochemical aspects of pulmonary acinar adenocarinoma, and the presence of malignant nodules distributed in the abdominal cavity of an adult female bovine.

\section{CLINICAL CASE}

A female bovine, Nelore breed, age nine, was received by the Department of Veterinary Pathology at the UNESP-Veterinary Hospital, Botucatu (SP), Brazil, for post mortem analysis. In the clinical history, clinical signs of hyperoxia, ruminal hypotonia, and persistent tachycardia were described during the first clinical examination. These clinical signs progressively intensified and 15 days after the first examination, an exploratory laparotomy was done where 50 liters of pink-colored abdominal fluid were drained and a mass in the left sacral wing with suspected mesothelioma was also observed. Due to the precarious economic condition of the animal owner, complementary procedures and examinations were not performed. Finally, with the authorization of the owner, the euthanasia of

\section{INTRODUCCIÓN}

Los tumores primarios de pulmón son raros en bovinos, por lo que es un hallazgo atípico en mataderos. La incidencia de estos tumores es del $2.8 \%$ entre todas las neoplasias encontradas para la especie (1).

Los tumores malignos de origen epitelial relacionados con el tejido pulmonar del bovino pueden surgir a partir del epitelio, glándulas mucosas de los bronquios (células caliciformes) y revestimiento alveolar. Esos tumores pueden ser subdivididos en cuatro tipos histológicamente distintos: papilar, acinar, sólido y mixto, los tipos papilar y acinar son los más frecuentes en los animales domésticos (2).

La metástasis de los carcinomas pulmonares ocurre por invasión local y por vía linfática o hematógena (1). Debido a la rara frecuencia de esta neoplasia en bovinos, poco se conoce sobre su comportamiento biológico. En Brasil, en un estudio retrospectivo realizado por Lucena et al (3), entre los años 1964 y 2008, se obtuvieron muestras en bloques de parafina de necropsias realizadas en 6706 bovinos, almacenadas en los archivos del servicio de Patología, Universidad de Santa María, Rio grande do Sul. De estas muestras, 586 eran neoplasias. Se determinó que cuatro adenocarcinomas eran de origen pulmonar, incluyendo dos adenocarcinomas papilares, uno acinar y uno de células pequeñas y anaplásicas. Sin embargo, fueron Viott et al (4) quienes describieron detalladamente el primer caso de adenocarcinoma pulmonar en este país.

El objetivo de este trabajo fue relatar la ocurrencia y describir los aspectos macroscópicos, histológicos e inmunohistoquímicos en un adenocarinoma acinar pulmonar, y la presencia de nódulos malignos distribuidos en cavidad abdominal de una hembra bovina adulta.

\section{CASO CLÍNICO}

Una hembra bovina de raza Nelore, de nueve años de edad, fue recibida en el Servicio de Patología Veterinaria del Hospital Veterinario-UNESP, Botucatu (SP), Brasil, para análisis post mortem. En la historia clínica fueron descritos signos clínicos de hiporexia, hipotonía ruminal y taquicardia persistente durante el primer examen clínico. Estos signos clínicos se intensificaron de forma progresiva y 15 días después del primer examen, se efectúo una laparotomía exploratoria donde se drenó 50 litros de líquido abdominal de color rosado y se observó además una masa en el ala sacral izquierda con sospecha de mesotelioma. Debido a la precaria condición económica del propietario del animal, procedimientos y exámenes complementarios no 
the animal was performed for academic purposes in the Veterinary Pathology sector.

During the necropsy, the animal obtained a body condition 3/5 (5), with oculo-palpebral mucous, oral and external genital of normal color. During In situ analysis, the lung showed areas of atelectasis in the cranial lobe, and left caudal, associated with multifocal fibrosis (Figure 1A), nodules between 1 and $4 \mathrm{~cm}$ in diameter were also present, with a firm consistency, ranging in color from white to yellow, and diffusely distributed in this organ (Figure 1B).

In the abdominal cavity, multi-sized nodules were observed, mainly in parietal and visceral serous, and diffusely distributed, measuring 0.2 to 2.0 $\mathrm{cm}$ in diameter (Figure $1 \mathrm{C}$ ). A mass of $10.0 \times 8.0$ $\mathrm{cm}$ was also observed in the left sacral wing. The nodule in the sacral region was mainly composed of adipose tissue encapsulating a neoplastic mass of $2 \mathrm{~cm}$ in diameter. The uterus was found to be thickened, with a firm consistency, and upon cutting, viscous, translucent content was noted.

Samples were collected from the: Lung, heart, spleen, liver, pancreas, kidney, uterus, intestine, brain and from nodules found in the lung and abdominal cavity. All were set in $10 \%$ formalin, and routinely processed, using the hematoxylineosin method.

The histopathological examination of the nodules revealed neoplastic epithelial cells with acini formation. The cells exhibited moderately sized, eosinophilic cytoplasm, basophilic round nucleus with basal localization (Figure 2A). Little chromatin was found, identifying one or two nucleoli per cell; further observations included: anisokaryosis, anisocytosis, high pleomorphism and increased nucleus:cytoplasm ratio. On average, two mitotic figures per high magnification field (400x) were determined. fueron realizados. Finalmente, previa autorización del propietario, la eutanasia del animal se llevó a cabo para fines académicos del sector de Patología Veterinaria.

Durante la necropsia, el animal obtuvo una condición corporal 3/5 (5), con mucosas oculopalpebral, oral y genital externa de color normal. Al análisis in situ, el pulmón presentó áreas de atelectasia en el lóbulo craneal y caudal izquierdo, asociada a fibrosis multifocal (Figura 1A), además de presentar nódulos entre 1 y $4 \mathrm{~cm}$ de diámetro, con consistencia firme, coloración que varió de blanco a amarillo y distribución difusa en este órgano (Figura 1B).

En cavidad abdominal, se observó principalmente en serosa parietal y visceral, y con distribución difusa, nódulos de múltiples tamaños, midiendo de 0.2 a $2.0 \mathrm{~cm}$ de diámetro (Figura 1C) y una masa de 10.0 x $8.0 \mathrm{~cm}$ en el ala sacral izquierda. El nódulo en la región sacral estaba constituido principalmente por tejido adiposo que encapsulaba una masa neoplásica de $2 \mathrm{~cm}$ de diámetro. El útero se encontró engrosado, con consistencia firme, al corte, se notó de aspecto viscoso y contenido translúcido.

Se colectaron fragmentos de: pulmón, corazón, bazo, hígado, páncreas, riñón, útero, intestino, encéfalo y de los nódulos hallados en pulmón y cavidad abdominal. Todos fueron fijados en formol al $10 \%$, y procesados rutinariamente, por el método de Hematoxilina-Eosina.

El examen histopatológico de los nódulos, reveló células epiteliales neoplásicas con formación de acinos. Las células exhibían citoplasma de tamaño moderado y eosinofílico, núcleo redondo, basofílico, y de localización basal (Figura 2A). La cromatina se encontró escasa, identificándose uno o dos nucléolos evidentes por cada célula; se observó además, anisocariosis, anisocitosis, alto pleomorfismo y relación aumentada núcleo:citoplasma. Se

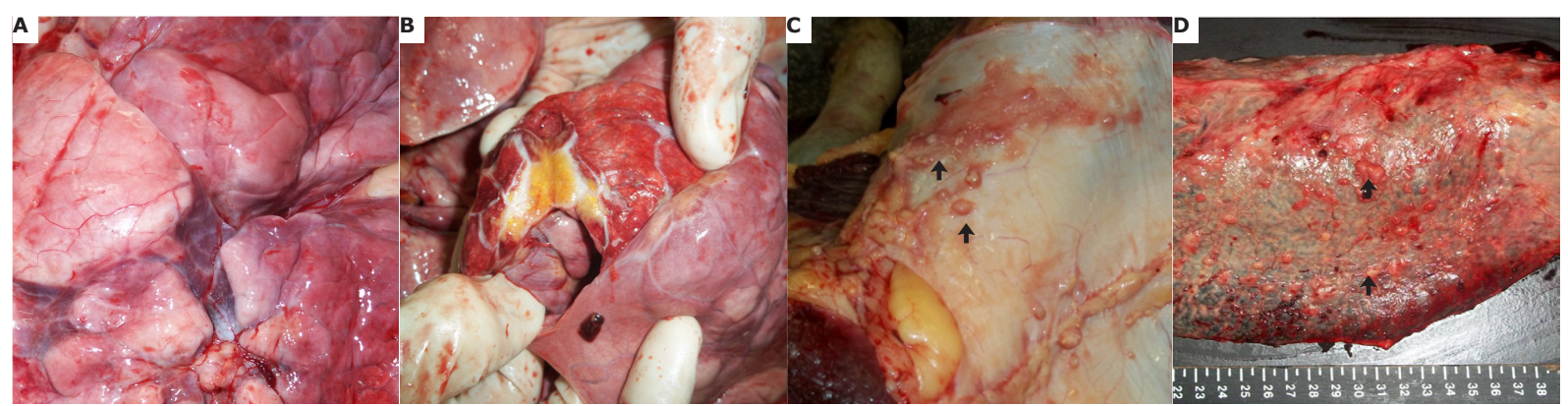

Figure 1. Macroscopic examination of bovine pulmonary acinar adenonocarcinoma. $1 \mathrm{~A}$ ) Multifocal fibrosis in the lung. 1B) Nodule in the lung, yellow with a firm consistency upon cutting. 1C) Multiple nodules in the abdominal cavity (Arrows). 1D Nodules in the spleen (Arrows). 
In some areas of the cut, multifocal and coalescing necrosis was found, mononuclear inflammatory cells predominantly infiltrated with lymphocytes, plasmocytes and discrete reactive macrophages. When performing Ziehl-Neelsen stain, the result was negative for Mycobacterium sp. (Figure 2B). Areas of mineralization and fibrosis, of moderate quantity, with multifocal and coalescent distribution were also identified. The spleen, sternal lymph node and abdominal nodes, showed infiltration of previously described neoplastic cells.

The Immunohistochemical technique by means of the endogenous peroxidase method was used for pan-cytokeratin (Mouse anti Cytokeratin (Pan) AE1/AE3, Invitrogen, Frederick, USA) (Dilution $1: 200 \mathrm{ul}$ ) and Vimentin (Mouse anti Vimentin (V9), Invitrogen, Frederick, USA) (Dilution $1: 1000 \mathrm{ul}$ ), both with cytoplasmic marking. For the revelation DAB was used (chromogen 3,3 'Diaminobenzidine, Dako, Glostrup, Denmark). determinó en promedio dos figuras de mitosis por campo de grande aumento (400x).

En algunas áreas del corte se halló necrosis multifocal y coalescente, infiltrado inflamatorio mononucleado predominando linfocitos, plasmocitos y discretos macrófagos reactivos. Al realizar la coloración de Ziehl-Neelsen esta resultó negativa a Mycobacterium sp., (Figura 2B). Se identificaron además, áreas de fibrosis y mineralización en cantidad moderada con distribución multifocal y coalescente. El bazo, el nódulo linfático esternal y los nódulos abdominales, presentaron infiltrado de células neoplásicas, descrita previamente.

La técnica de inmunohistoquímica por el método de peroxidasa endógeno fue utilizada para Pancitoqueratina (Mouse anti Cytokeratin (Pan) AE1/AE3, Invitrogen, Frederick, USA) (Dilución $1: 200 \mu \mathrm{l})$ y Vimentina (Mouse anti Vimenetin (V9), Invitrogen, Frederick, USA) (Dilución $1: 1000 \mu \mathrm{l})$, ambas de marcación citoplasmática. Para la revelación fue utilizado DAB (cromógeno 3,3’Diaminobenzidine, Dako, Glostrup, Dinamarca).
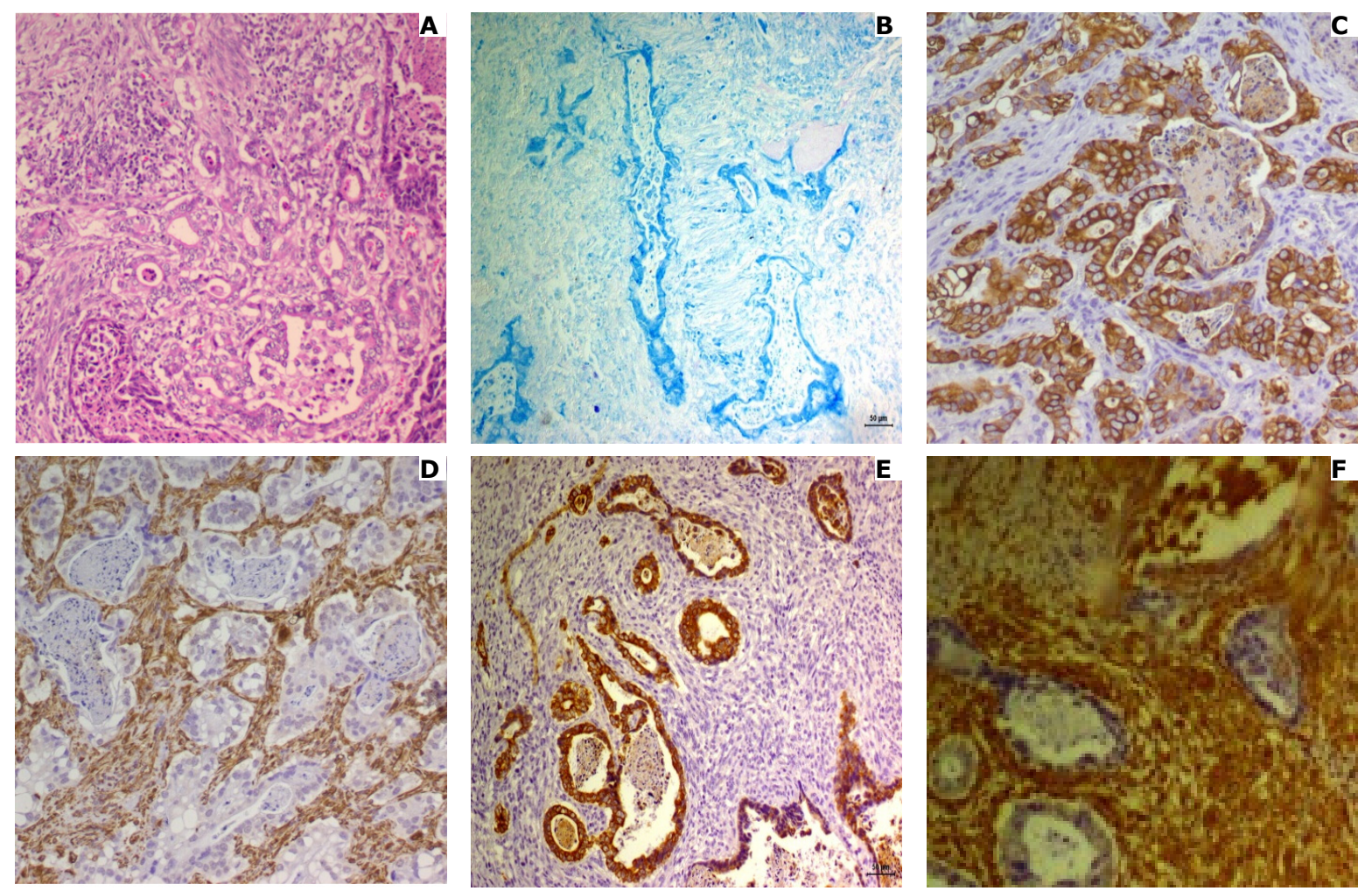

Figure 2. Microscopic examination of bovine pulmonary acinar adenocarcinoma. 2A) Formation of alveoli through neoplastic cells, lung, HE, 400x. 2B) Ziehl-Neelsen staining, lung, 200x. 2C) Immunohistochemistry with positive reactivity to neoplastic epithelial cells, cytokeratin antibody AE1/AE3, lung, 100x. 2D) Positive immunohistochemical reaction in connective tissue and negative in neoplastic epithelial cells, vimentin antibody, lung, 100x. 2E) Positive marking of neoplastic cells, antibody AE1/AE2, nodule in the sacral wing, 100x. 2F) Positive immunohistochemical reaction in connective tissue and negative in neoplastic epithelial cells, vimentin antibody, nodule in the sacral wing, 100x. 
The immunohistochemistry test showed positive immunoreactivity for cytokeratin, being moderately cytoplasmic and diffused in neoplastic cells (Figure 2C, 2E). In malignant cells, no Vimentin marking was observed, this antibody was only positive for connective tissue (Figures 2D, 2F).

According to morphological, anatomical, and histopathological findings and to positive immunoreactivity for cytokeratin, the tumor was characterized as acinar adenocarcinoma in the lung and in the nodes identified in the abdominal cavity.

\section{DISCUSSION}

Pulmonary malignant neoplasms are classified according to their origin, epithelial cells in the lung originate lung adenocarcinomas $(1,3,6)$, while the mesenchymal cells can produce osteosarcomas, chondrosarcomas, hemangiosarcomas, malignant histiocytosis, lymphomatoid granulomatosis, granular cell tumors and mesothelioma (7).

Pulmonary adenocarcinoma may be differentiated from mesothelioma by the presence of basal, uniform nuclei in cells that form acini, a feature which is absent in mesotheliomas, which have granular cells with irregular nuclei and primitive acini (8).

Additionally, immunohistochemistry is a useful tool in differentiating these tumors, since neoplastic cells in mesothelioma express epithelial cytokeratin and mesenchymal markers, such as Vimentin (9), whereas adenocarcinomas are specifically marked by cytokeratin.

Pulmonary adenocarcinomas, with esquirrosa, in cattle should be differentiated from other epithelial neoplasms, mainly primary neoplasms of the uterus and pancreas $(3,9)$. Endometrial adenocarcinoma, besides being esquirroso and possessing large amounts of fibrous tissue, presents a disruption in glandular epithelial cells and high pleomorphism. This was not evident in uterine tissue and nodules scattered in the abdominal cavity of the animal under study (9). Moreover, pancreatic adenocarcinoma exhibits several cellular patterns: tubular, not delineated or solid. The cells may form acini or gross tubules, with a uniform, oval nucleus and dispersed chromatin. These tumors have areas of hemorrhage, mineralization or necrosis in the pancreas (7); the absence of macroscopic and microscopic alterations in this organ repudiate the emergence of this carcinoma
La prueba de inmunohistoquímica evidenció inmunoreactividad positiva para citoqueratina, siendo ésta citoplasmática moderada y difusa en las células neoplásicas (Figura 2C, 2E). En las células malignas no se observó marcación con Vimentina, este anticuerpo solo fue positivo para el tejido conjuntivo (Figuras 2D, 2F).

Conforme a los hallazgos morfológicos, anatómicos, histopatológicos y a la inmunoreactividad positiva para citoqueratina, el tumor fue caracterizado como adenocarcinoma acinar en el pulmón y en los nódulos identificados en la cavidad abdominal.

\section{DISCUSIóN}

Las neoplasias malignas pulmonares son clasificadas de acuerdo con su origen, las células epiteliales del pulmón originan los adenocarcinomas pulmonares $(1,3,6)$, mientras que las células mesenquimales pueden producir osteosarcomas, condrosarcomas, hemangiosarcomas, histiocitosis maligna, granulomatosis linfomatoide, tumor de células granulares y el mesotelioma (7).

El adenocarcinoma pulmonar puede ser diferenciado del mesotelioma por la presencia de núcleos basales y uniformes de las células que forman acinos, una característica que se encuentra ausente en los mesoteliomas, los cuales poseen células granulares con núcleos irregulares y acinos primitivos (8).

Adicionalmente, la inmunohistoquímica es una herramienta útil para la diferenciación de esos tumores, puesto que las células neoplásicas del mesotelioma expresan citoqueratinas epiteliales y marcadores mesenquimales, tales como la Vimentina (9), mientras que los adenocarcinomas son marcados específicamente por las citoqueratinas.

Los adenocarcinomas pulmonares con característica esquirrosa en bovinos deben diferenciarse de otras neoplasias epiteliales, principalmente, neoplasias primarias de útero y páncreas $(3,9)$. El adenocarcinoma endometrial además de ser esquirroso y poseer grandes cantidades de tejido fibroso, presenta desorganización en las células epiteliales glandulares y alto pleomorfismo. Lo cual, no fue evidenciado en el tejido uterino y los nódulos diseminados en cavidad abdominal del animal en estudio (9). Por otro lado, el adenocarcinoma pancreático exhibe varios patrones celulares: tubulares, no delineados o sólidos. Las células pueden formar acinos o túbulos groseros, con núcleo uniforme, oval, y cromatina dispersa. Esos tumores presentan áreas de hemorragia, mineralización o necrosis en el páncreas (7); la ausencia de alteraciones macroscópicas y microscópicas en este órgano descartó el surgimiento de este carcinoma. 
During the necropsy, the cheesy and calcareous appearance of the nodules suggested tuberculosis. However, histological sections subjected to the Ziehl-Neelsen stain were negative.

In humans, infection with Mycobacterium sp. was already associated with pulmonary adenocarcinoma $(10,11)$. However, until now there has not been any report of animals associated with these diseases.

In conclusion, anatomical and histomorphological findings, and contributions described in the literature allow the tumor to be classified as lung acinar adenocarcinoma, this pattern of organization was also identified in the nodules collected from the abdominal cavity; suggesting that the primary focus of the neoplasm was from pulmonary origin. Positive immunoreactivity for $A E 1 / A E 3$ and negative marking for vimentin were key determinants in completing the case.
Durante la necropsia el aspecto caseoso y calcáreo de los nódulos sugirió tuberculosis. Sin embargo, las secciones histológicas sometidas a la coloración de Ziehl-Neelsen resultaron negativas. En humanos ya fue asociada la infección por Mycobacterium sp., con el adenocarcinoma pulmonar $(10,11)$. Sin embargo, hasta ahora no se tiene ningún relato sobre animales en los que se hayan asociado estas enfermedades.

En conclusión, los hallazgos anatómicos, histomorfológicos, y los aportes descritos en la literatura permitieron clasificar el tumor como adenocarcinoma acinar pulmonar, este patrón de organización también fue identificado en los nódulos colectados en la cavidad abdominal; sugiriendo que el foco primario de la neoplasia fue de origen pulmonar. La inmunoreactividad positiva para $A E 1 /$ AE3 y la marcación negativa para vimentina fueron determinantes para concluir el caso.

\section{REFERENCES}

1. Ioan A, Câtoi C. Comparative Oncology. 1 Edition. Bucuresti: The Publishing House of the Romanian Academy; 2007.

2. Barley JP. Pulmonary papillary adenocarcinoma in an adult cow. Ir Vet J 2011; 1(12):674-675.

3. Lucena RB, Rissi DR, Kommers GD, Pierezan F, Oliveira-Filho JC, Macedo JTS. A retrospective study of 586 tumours in brazilian cattle. J Comp Path, 2011; 145:20-24.

4. Viott AM, Langohrii IM, Vannucci FA, Almeida AP, Leite RC, Ecco R. Adenocarcinoma pulmonar em um bovino. Ciênc Rural, 2010; 40(2):484-487.

5. Correa-Orozo A, Uribe-Velásquez LF, La condición corporal como herramienta para pronosticar el potencial reproductivo en hembras bovinas de carne. Rev Fac Nal Agr Medellín, 2010; 63(2):5607-5619.

6. Carminato A, Bozzato E, Trevisan L, Vascellari M, Catania S, Palma D, et al. Bovine pulmonary blastoma. Large Anim Rev, 2008; 14(1):3-5.

7. Santos, R. L.; Alessi, A.C. Patologia Veterinaria. Edición 1. São Paulo: Roca; 2011.
8. Merlo W, Rosciani A, Koscinczuk P, Ortega $\mathrm{H}$, Insfrán RM, Macció OA. Mesotelioma peritoneal en un canino. Rev Vet 2007; 18(1):54-57.

9. Stilwell G, Peleteiro MC. Uterine adenocarcinoma with pulmonary, liver and mesentery metastasis in a hostein cow. Vet Med Int 2010; Article ID 727856. http:// dx.doi.org/10.4061/2010/727856

10. Kobashi Y, Yoshida K, Miyashita N, Niki Y, Matsushima T. Pulmonary Mycobacterium avium disease with a solitary pulmonary nodule requiring differentiation from recurrence of pulmonary adenocarcinoma. Intern Med, 2004; 43(9):855-859.

11. Sawai T, Soda H, Kohno S. Mycobacterium intracellulare pulmonary infection which coexisted and mimicked lung cancer. Intern Med 2008; 47(5):459-462. 